https://doi.org/10.31470/2706-7904-2020-15-168-170

\title{
ФОРМУВАННІ МОВНОЇ КОМПЕТЕНТНОСТІ СТУДЕНТІВ В УМОВАХ ДИСТАНЦЙНОГО НАВЧАННЯ
}

\section{Formation of Students' Language Competence in Conditions of Distance Learning}

\author{
Magdalyna Lyla \\ Ph.D. in Psychology, Assistant Professor \\ Pereiaslav-Khmelnytskyi Hryhorii Skovoroda State Pedagogical University (Ukraine) \\ magdalyla@ukr.net \\ https://orcid.org/0000-0002-4321-0679

\section{Diana Chyzhma} \\ Ph.D. in Psychology, Assistant Professor \\ Pereiaslav-Khmelnytskyi Hryhorii Skovoroda State Pedagogical University (Ukraine) \\ dianachyzhma@ukr.net \\ https://orcid.org/0000-0001-9850-5143
}

\begin{abstract}
The abstract reveals the problem of formation in students the language competence in condition of distance learning. The language competence of an individual is a determining factor of his education and intelligence. The success in distance learning depends, first of all, on a certain level of linguistic training, the presence of formed skills and abilities, as well as the desire to learn. At the same time, the provision of constant pedagogical support, regular monitoring of learning outcomes, as well as providing students with support in the educational process is of great importance.
\end{abstract}

Key words: language competenc, distance learning, motivation, organization of educational activity.

\section{Вступ \\ Introduction}

У зв’язку з пандемією короновірусу особливої уваги потребують питання організації навчального процесу в закладах освіти, зокрема дистанційного навчання, яке передбачає застосування сукупності сучасних технологій для забезпечення передачі інформації в інтерактивному режимі за допомогою використання інтерактивних комунікативних технологій. 
Мотиваційний фактор є одним 3 найбільш важливих аспектів проблеми дистанційного навчання, адже кожен викладач знає, що навчання протікає більш успішно, якщо у студента сформована позитивна мотивація, пізнавальний інтерес, потреба в здобутті знань, почуття обов'язку, відповідальність та інші мотиви. Вагомим мотивом у студентів $\epsilon$ інтерес до майбутньої професії, прагнення відповідати високому рівню вимог, які висуває суспільство до молодих фахівців. Звідси, мотивуючим чинником в умовах дистанційного навчання має бути орієнтація змісту навчального матеріалу на життєві потреби студентства, їхні інтереси, уподобання, використання професійно орієнтованого та практично спрямованого матеріалу. Однак, завдання повинні бути не лише цікавими й зрозумілими, а й посильним для студента.

\section{Результати \\ Results}

Інтересу до змісту навчання сприяє використання таких питань і завдань, рішення яких вимагає від студентів активної пошукової діяльності. За допомогою проблемних ситуацій забезпечується розвиток теоретичного мислення, пізнавальний інтерес до змісту дисципліни, формування спостережливості, вміння критично аналізувати інформацію, здатність підходити до роботи нестандартно і знаходити ефективне розв'язання проблеми.

Формування мовленнєвої компетентності є невід'ємною складовою навчання кожного фахівця і набуває особливої актуальності в сучасних умовах, що склалися, оскільки комунікація забезпечує можливість не лише вирішувати комунікативнопізнавальні задачі засобами спілкування, висловлювати власні думки та розуміти співрозмовника, а й веде до професійного успіху. Мовна компетентність особистості $є$ визначальним фактором iї освіченості та інтелігентності. Сучасний фахівець для досягнення успіху та цілей повинен вміти швидко адаптуватися до змін і ритму життя.

Як відомо, успіх у навчанні в умовах дистанційного навчання залежить, перш за все, від готовності студентів до цього виду діяльності, певного рівня їх лінгвістичної підготовки, наявності в них сформованих навичок та вмінь, а також бажання навчатися. При цьому великої ваги набуває забезпечення постійного педагогічного супроводу, регулярне відстеження результатів навчання, а також надання студентам підтримки в освітньому процесі.

Важливим фактором ефективності навчального процесу $\epsilon$ організація самостійної навчальної діяльності студентів, формування у них навиків самоосвіти та саморегуляції, готовності до постійного поповнення знань. Етап самостійної роботи 3 
іноземної мови передбачає самостійне виконання лексичних, граматичних або фонетичних вправ різного типу, самостійне опрацювання текстів, діалогів, пошук певної інформації, написання творчих робіт (есе), підготовка рефератів, доповідей 3 наступною усною презентацією в он-лайн режимі. Он-лайн навчання розширює можливості студентства у плані часу та місця вивчати програмний матеріал.

Існує велика кількість засобів та платформ для проведення дистанційного навчання. Найпопулярніші з них Microsoft Teams, Zoom та Skype, які є не складними у користуванні й зручними з огляду на індивідуальне і групове спілкування, демонстрації на екрані, спілкування в чат-режимі тощо.

Якість та ефективність занять зовсім не втрачається за умови хорошого Інтернет з’єднання, оскільки як і при традиційному навчанні в аудиторії тут присутні взаємодія викладача і студента, спілкування, перевірка домашнього завдання, обговорення теми, яка вивчається та здійснюється контроль 3 боку викладача за допомогою он-лайн тестів, які виконуються інтерактивно у режимі реального часу, що гарантує прозорість та достовірність результатів.

Використання таких форм роботи, як робота 3 оригінальними джерелами інформації (текстами за фахом, газетними статтями), виступи 3 доповідями та презентаціями на он-лайн заняттях сприяє поглибленню й розширенню знань студентів, активізує їх пізнавальну діяльність, створить належні умови для самореалізації студента як особистості, що дозволить йому самому визначити додаткові навчальні цілі та спонукатиме його до подальшої систематичної роботи в поза аудиторний час. Як показали дослідження, під час навчання в Інтернеті знижується тривога і студенти стають більш впевненими. Звичне оточення, близькі друзі й рідні поруч - відсутність стресу адаптації та соціалізації підвищують й мотивацію до навчання.

\section{Висновки Conclusions}

Нині вивчення іноземної мови дистанційно або через скайп користується величезною популярністю, адже за допомогою онлайн-сервісів студент сам вибирає відповідний графік навчання незалежно від місця знаходження чи проживання. Результатом сформованості мовної компетентності виступає мовна особистість, що характеризується такими якостями, як розкутість, творчість, самостійність, здатність будувати взаємодію й взаєморозуміння 3 партнерами спілкування та включатися в сучасні світові процеси розвитку суспільства. 